\title{
The word reading performance of grade $V$ pupils through a library hour program in Philippines
}

\author{
Velvet C. Figuracion ${ }^{1}$ Rashid Ceazar G. Ormilla ${ }^{2}$ \\ ${ }^{1}$ Faculty, Alfonso Lista Central School, Department of Education, Philippines \\ ${ }^{2}$ Chairperson, BEEd Program, College of Education, Ifugao State University - \\ Potia Campus, Philippines \\ *e-mail: ormillarashidceazar@gmail.com
}

Received: 01 October 2020; Accepted: 02 June 2021; Published: 03 June 2021

To cite this article (APA): Figuracion, V. C., \& Ormilla, R. C. G. (2021). The word reading performance of grade $\mathrm{V}$ pupils through a library hour program in Philippines. EDUCATUM Journal of Social Sciences, 7(1), 95103. https://doi.org/10.37134/ejoss.vol7.1.10.2021

To link to this article: https://doi.org/10.37134/ejoss.vol7.1.10.2021

\begin{abstract}
The purpose of this study is to determine the significance of Library Hour Program towards word reading performance of public elementary grade five pupils. The true experimental design used consisted of experimental and control groups in which experimental group received the intervention while the control group had no intervention given. The instrument used was the standardized Philippine Informal Reading Inventory (Phil-IRI) developed by the Department of Education- Bureau of Learning Delivery to measure the significance of Library Hour Program in improving pupils word reading levels. T-test were carried out to answer the research objectives of the study. There were 72 grade five pupils who participated in the experimental group. Pupils that can read atlevel text was determined through the Group Screening Test. The pupils with scores less than fourteen (14) out of twenty (20) literal, inferential, and critical questions were subjected to pretest and posttest and served as the experimental group in the study. The pretest and posttest determined the reading level of pupils whether under frustration, instructional, and independent. Phil-IRI graded passages were used in this study. These graded passages were given by the Department of Education and were used to assess the reading performances of Grade Three to Six in the elementary grades nationwide. The library hour as a reading intervention program was specifically used in Alfonso Lista Central School as it was included in their daily classroom programs for thirty (30) minutes a day. After five months of conducting the intervention program, the findings revealed that during the pretest, pupils were assessed under the Instructional level. It also showed that during the posttest, pupils were found to be under the Independent Level. The results showed that Library Hour as an intervention program to improve the word reading of grade five pupils was effective. This also revealed that regardless of sex, Library Hour was found very effective. It was then recommended to include the Library Hour in the daily classroom program in schools as it was proven useful to increase pupils' reading ability.
\end{abstract}

Keywords: Phil-IRI, frustration level, instructional level, independent level

\section{INTRODUCTION}

Good reading performances are developed through good reading habits. Reading is a prerequisite of an effective study habit and have been correlated with academic achievement (Daniel et al., 2017 \& Balan et al., 2019). Palani (2012) also mentioned that reading habit has been a vital aspect to create an educated society in this world. He purported that reading effectively is an essential way for learning effectively. He argued further that, at present, the importance of reading habits have been disregarded among young and old because of the great influence of different technology. Technology influence the reading habits of the learners as they prefer watching, surfing, or just playing mobile games over reading. The need to motivate pupils intrinsically to have a good reading habit played a vital role in their performance (Liu \& Hou, 2017, Korantwi-Barimah et al., 2017, Omela \& Martin 2020). Deavers 
(2000) described reading as an intellectual work which is possible when an individual forms a reading habit. Thus, reading have an important role in enabling individual to attain a practical effectiveness. Bulwer-Lytton said, "Laws die but books never" since books are the most suitable channel through which knowledge is passed down through generations (Issa et al., 2012). Additionally, Douglas (2000) asserted that in order to become responsible individual in the society and become successful in school, every child needs to be fully competent in reading. The ability for a child to read well is vital to become successful in life. As Tracy and Matsumoto (2008) articulated that the only form of entertainment that is essential skill in life is reading. It is a skill that must be nurtured from a child's earliest years. The time that children know already how to read, support is still needed to reach their full potentials as readers. Furthermore, Ogdobo (2010) affirmed that reading ascertain the academic attainment of learners to a very high extent. Besides, the library also plays a vital role in improving learners' reading performances. This is because when learners' have access to a lot of good books and good libraries, they read more and thus do better at reading tests (Krashen, 2004).

In the Philippines, the Department of Education is encouraging school learners to read instead of giving much time on the Internet. In DepEd Memorandum No. 244 series of 2011, school officials were encouraged to conduct reading activities in schools such as the Read-a-Thon, "Drop Everything and Read (Dear)" and remedial reading classes for learners. This program is a DepEd move to institutionalize the national "Every Child a Reader" program. This program makes reading relevant again to the youth amidst the growing reliance on the interned inclination to online activities. This includes activities, such as the Read-a-Thon, which aims to discover outstanding readers in class; while the Dear program, which engages learners in 15 to 20 minutes of reading daily; and the shared reading or readers' mentoring program, where older students need to support younger readers with reading difficulties.

Additionally, DepEd Memorandum No. 244 (2011) has stated that schools should foster partnerships with the non-government organizations and private sectors for further collaboration within the community and to optimize the success of reading activities. Poor reading habits among children affect their academic performances in schools (Asagwara, 2001). This results in poor academic performances. This problem has already been observed not only in the different parts of the world but also in the Philippines. To pin out these reading problems and difficulties, assessing learners' capabilities in reading should be done. Weaver (2014) has suggested that the informal reading inventory defined as an informal reading tests consisted of a set of graded passages administered to individual learners to be used. This is in contrast to the formal reading tests that are standardized and often conducted to compare a learner's performance with others. The informal reading tests are meant to give a greater perception to the reading level of individual learners concerning a specific passage to allow teachers to customize instruction necessary for their learners' needs (Rutledge, 1998).

The Philippine Informal Reading Inventory (Phil-IRI) is a program of the Department of EducationBureau of Learning Delivery that straightly caters every Filipino to become a reader. This is in conform to the flagship program of the DepEd that "Every Child A Reader Program," purposely to make every Filipino child a reader and a writer at his/her grade level.

The Phil-IRI aims to identify the performance of the individual learner's in silent reading, oral reading, and listening comprehension which consisted of graded passages. There are three types of assessments seeking to determine the learner's reading level whether it is independent, instructional, and frustration level. Afterwards, the data gathered from these measures are used to design or adjust classroom instruction, small group, or individualized instruction to fit the learners' needs and abilities. The school reading performance makes use of the data as the basis in planning, designing/redesigning the reading programs or activities in order to improve the overall reading performance of the school. It is made to provide teachers with a tool for measuring and describing reading performance. It is an assessment tool consisted of graded passages designed to determine a learner's level of reading. It is worthy to note that the Phil-IRI only provides an approximation of the learner's ability and may be used in combination with other reliable tools of assessment. The development of the Phil-IRI is one of the initiatives put in place in support of the "Every Child A Reader Program" (ECARP). Teachers should be acquainted 
with the learners' current reading levels and abilities before they can create and provide appropriate reading instruction. This diagnostic approach describes how children read embraces inclusionary principles that emphasize the need for education that is learner-oriented, responsive, and culturally sensitive. Thus, teachers consider Phil-IRI as one of the diagnostic tools to determine learners' abilities and needs in reading.

Alfonso Lista Central School has revealed the poor reading performances of the pupils too as it was reflected by the Phil-IRI Form 2 (Group Screening Test). The Phil-IRI Form submitted by the school showed that two hundred ninety-three (293) out of four hundred twenty-five (425) pupils did not meet the standard reading performance in grades four to six. Specifically, seventy-two out of one hundred forty-seven grade five pupils read below at-level texts. It shows that pupils are experiencing difficulty reading at-level text. Having been exposed to this scenario, the researchers opted to take a careful examination and analysis of this phenomenon. As the outcome, the researchers would want to suggest a reading intervention program that can help to reduce the reading problems.

\section{CONCEPTUAL FRAMEWORK}

To have an efficient and effective reading program: designing, implementing and sustaining to achieve an optimum success are very important. Reading strategies and approaches are developed to improve the reading performances and also to address the reading difficulties of every pupil. Effective reading programs require a well-planned and a continuous professional development to equip educators with the needed knowledge in order to have an effective reading instruction. It also requires the selection of appropriate tools that are tightly linked to research. Likewise, school leadership initiatives to ensure smooth implementation and enduring effects of reading programs are also needed as a support system. Many publishers suggest reading programs and recommend them as the best possible instructional tool that can help improve pupils' reading capabilities. Hence, in order to solve reading problems, reading assessments must be done.

Torgesen (2005) had identified the selection and implementation of well-designed, research-based core reading programs as the first step in the model designed to prevent reading difficulty in most children. Once a school selects an instructional program, it is crucial that the program must be fully implemented with high fidelity. This study aimed to follow this style. The researcher had pointed out the poor reading levels of the pupils through a series of reading assessment tools. Then, the researcher tested the significance of the reading intervention program which is the Library Hour. Once it is found as an effective tool in leveling up the word reading level of the pupils, the researcher would suggest for full implementation of the said reading intervention program.

Reading intervention programs will be the key to help children become good readers. Through reading intervention programs, the confidence of the children will be restored. It is also a valuable method in increasing children's reading speed. It will also help build and expand children's vocabulary. Generally, through reading intervention programs, children can improve their reading performance. Repeated reading is essential in improving reading fluency skills. To improve the word reading levels of pupils, it is a must to develop their habit in reading. Library Hour as a reading intervention program was chosen as a tool in improving the word reading level of this study. The paradigm of the study shown below served as the "worldview" for the development of the research. 


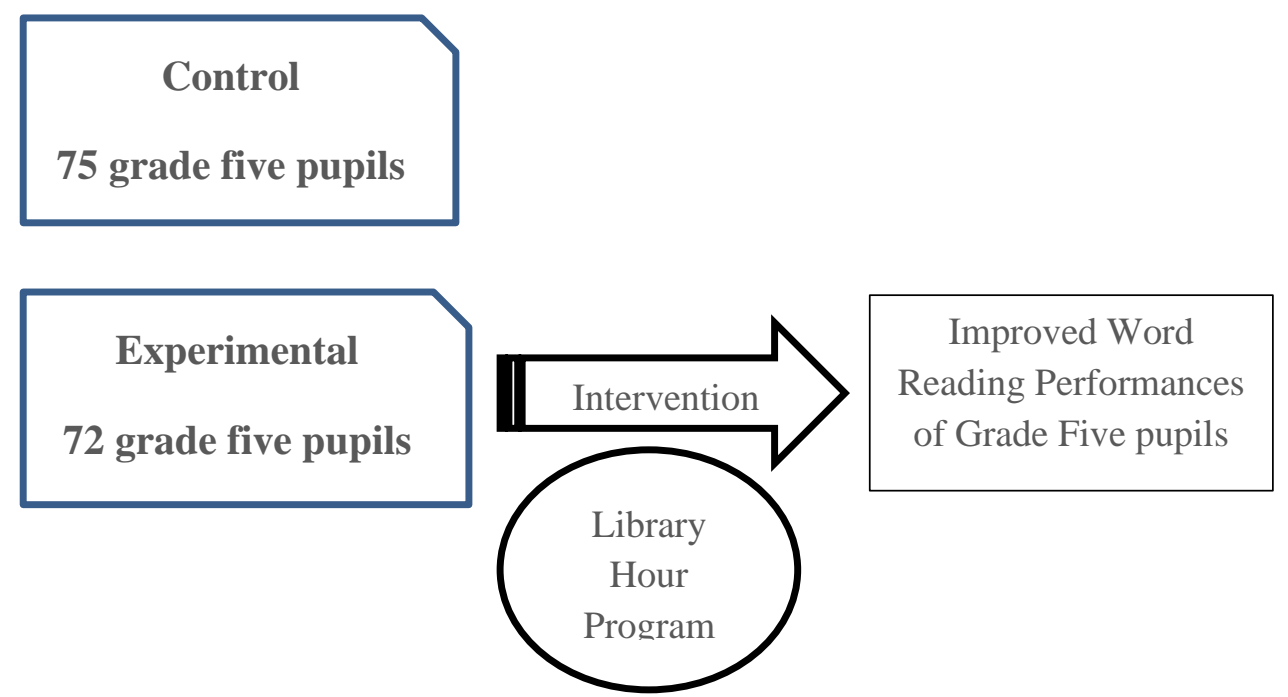

Therefore, the purpose of this study is to determine the reading performances of grade five pupils of Alfonso Lista Central School through the Library Hour Program. Specifically, it seeks to: (1) Determine the word reading level of the respondents during the pretest; (2) Identify the word reading level of the respondents during the posttest; (3) Analyze the difference between the word reading pretest score and word reading posttest score of the respondents; and (4) Analyze the difference of the word reading pretest score and word reading posttest score in terms of gender.

\section{METHODOLOGY}

This study used the true experimental design particularly the pretest-posttest control-group design. The design consisted of experimental and control groups in which experimental group receive the intervention while the control group has no intervention given (Sharma et al., 2019). The 10 to 11 years of old grade five pupils who got a score of fourteen and above during the group screening test (GST) were in the controlled group. On the other hand, pupils with scores lower than fourteen were in the experimental group. This study was conducted in Alfonso Lista Central School, Alfonso Lista Ifugao, Philippines. The assessment tool used was the standardized, Philippine Informal Reading Inventory (Phil-IRI) adapted from the Department of Education-Bureau of learning Delivery. This is an informal individualized assessment tool designed to determine a pupil's reading level (DepEd-BLD Phil-IRI Manual, 2018). With this, the researchers opted to conduct this study to the five sections of Grade Five pupils in Alfonso Lista Central School and has a total of one hundred forty-seven (147) number of enrollees in Grade Five who underwent the Phil-IRI Group Screening Test (GST). Among the grade five pupils who were tested during the Group Screening Test (GST), seventy-two (72) were revealed to have reading performances below the at-level texts. These pupils served as the respondents in this study. In gathering the needed data, the researcher used the Phil-IRI Forms. Phil-IRI Form 1 was used for the Group Screening Test (GST). It was used to determine the pupils who can read at-level passages. Phil-IRI Form 2 was utilized in summarizing the data gathered in the Phil-IRI Form 1. On the other hand, the Phil-IRI Form 3A was used during the Pretest and Posttest. These forms were also used to record the different types of miscues read by the pupils.

The researchers got the permission from the School Head of Alfonso Lista Central School to integrate their experimental study during the conduct of the Philippine Informal Reading Inventory (Phil-IRI). During the conduct of the Phil-IRI, the Group Screening Test (GST) was first done. The Phil-IRI Group Screening Test (GST) is a silently-administered test in both Filipino and English. The tool composed a 20 -item comprehension test based on a set of leveled passages for each grade level covering Grades 3 to 6 in Filipino and Grades 4 to 6 in English. The 20-item literal, inferential and critical questions were structured to test pupils' reading comprehension skills; literal questions in which the answers were explicitly stated in the text, inferential questions in which the answers were not explicitly stated in and 
critical questions which required the learner to analyze, synthesize and make judgments on the author's ideas. The passages were written and selected based on concept load, level of vocabulary used, sentence complexity, nature of themes, and cohesion. The Phil-IRI Group Screening Test (GST) is used by teachers to tell whether students are reading at, above, or below their grade levels. The result of the Group Screening Test (GST) served as the basis in identifying the number of pupils subjected to pretest.

Pupils who scored more than fourteen discontinued the Phil-IRI, thus, served as the control group during the study. Pupils with a score of less than 14 were subjected to pretest and were distributed into the experimental group of the study. Pupils with a raw score of 0-7 in the GST were given a passage that is three grade levels below his current level during the pretest while those with a raw score of 8-13 in the GST were given a passage 2 grades below his current level. The administration of Pre-Test classified the pupils as Independent, Instructional, Frustration, and Non- Reader in their Word Reading Level and Reading Comprehension Skills through Oral Reading and Silent Reading (Flippo, 2014). Pupils under Independent Reading Level can function on their own with almost perfect oral reading and excellent comprehension, those under the Instructional Reading Level profit the most from teacher-directed instruction in reading, while those under Frustration Reading Level find reading materials so difficult that they cannot successfully respond to them (Flippo, 2014).

After the conduct of the Phil-IRI pretest, the reading intervention program was used, to promote the word reading efficiency of the learners. School Library Hour was then set by the ALCS through the initiative of the school head, the school Phil-IRI coordinator, and the grades III-VI teachers. She also added that Library hour did not mean spending time in the library for reading purposes. Instead, pupils stay in their respective classrooms and read books from the District Library borrowed by the teacher. Usual activities during reading hours such as mentoring slow learners, answering questions from the texts or stories read, echo reading, reading in chorus were observed during the thirty-minute reading period. One of the researchers monitored the conduct of the intervention.

After five (5) months of reading interventions, the reading performances of the pupils were again tested through the post-test. The experimental group was given a new set of reading materials from the PhilIRI Manuals that aimed to evaluate their reading performance. There are four parallel sets of Phil-IRI Posttests (SETS A-D) that they can choose from. The Phil-IRI data were collected, tallied, correlated, and subjected to statistical treatment and interpretation. The frequency counts and the weighted mean were employed to treat the data that answers the descriptive research questions while the paired t-test was used in treating the organized data in response of the hypotheses of the study.

Notably, one of the researchers was a grade five teacher of that same school. She monitored the implementation of the intervention program for five months in the different grade five classes to ensure its successful implementation.

\section{FINDINGS AND DISCUSSIONS}

\section{Word Reading Level during Pretest}

Table 1 shows the word reading level of Grade five pupils during the pretest. This indicated that the weighted mean of 1.71, grade five pupils word reading level are under the instructional reading level. Pupils under this reading level are asked to re-read a story on which they have already received instruction from the teacher. Additionally, readers in this level profit mostly from the directed instruction given by the teacher in reading (Lehr, et al 2004). Pupils under this level can read the gradelevel passage with the support of the teacher (Phil-IRI Manuals, 2018). Their progress is dependent on the quality of instruction provided by the teacher. However, the table also shows that thirty-four (34) of the respondents are under the frustration reading level. Flippo (2014) posited that pupils in the frustration reading level cannot respond to the reading materials since they considered it to be difficult to read. Hence, Phil-IRI administers graded passage or text that is appropriate for their grade level in terms of content and readability. This shows that the respondents did not meet the standard word reading 
level and that they are below the at-level text. Moreover, twelve (12) of the respondents also reached the independent reading level where they can read on their own with an oral reading score of almost perfect.

Table 1. Word reading level of the Grade V pupils during the Pre-test

\begin{tabular}{|c|c|c|c|c|}
\hline \multirow[t]{2}{*}{ Reading Level } & \multicolumn{3}{|l|}{ Pre-test } & \multirow{2}{*}{$\begin{array}{l}\text { Reading Level } \\
\text { Interpretation }\end{array}$} \\
\hline & Frequency & Scale & $\begin{array}{l}\text { Weighted } \\
\text { Mean }\end{array}$ & \\
\hline Frustration & 34 & 1 & & \\
\hline Instructional & 26 & 2 & 1.71 & Instructional \\
\hline Independent & 12 & 3 & & \\
\hline
\end{tabular}

\section{Word Reading Level of the Grade V Pupils during the Post-test}

The word reading level of the pupils during the posttest as shown in Table 2 is independent with a corresponding weighted mean of 2.53. This result revealed that after the library hour intervention, the respondents' reading proficiency have improved from instructional to independent reading level. At this level, readers can function on their own with an oral reading of almost perfect and an exceptional comprehension (Flippo, 2014). Furthermore, the result of the posttest manifests that reading intervention programs such as the Library Hour improves the reading skill of the pupils. Only three (3) of the respondents are under the frustration reading level while twenty-eight (28) are under instructional level.

Table 2. Word reading level of the Grade V pupils during the Post-test

\begin{tabular}{|c|c|c|c|c|}
\hline \multirow{2}{*}{ Reading Level } & \multicolumn{3}{|l|}{ Post-test } & \multirow{2}{*}{$\begin{array}{l}\text { Reading Level } \\
\text { Interpretation }\end{array}$} \\
\hline & Frequency & Scale & $\begin{array}{l}\text { Weighted } \\
\text { Mean }\end{array}$ & \\
\hline Frustration & 3 & 1 & & \\
\hline Instructional & 28 & 2 & 2.53 & Independent \\
\hline Independent & 41 & 3 & & \\
\hline
\end{tabular}

\section{Significant Difference on the Word Reading Level of the Grade V Pupils Before and After the Library Hour intervention}

As presented on Table 3, the computed t-test value of 14.36 is greater than the critical value of 1.99 which means that when the t-test is greater than the t-critical value, the null hypothesis is rejected and the alternative hypothesis is accepted. This further means that conducting a Library Hour reading intervention is effective among the grade five pupils. The table further shows that the number of pupils under the frustration level during the pretest decreased from thirty (34) to three (3) during the posttest. Besides, the number of pupils under the instructional level increased from twenty-six (26) during the pretest to twenty-eight (28) during the posttest. The result indicates a remarkable increase in the number of pupils under the independent level from pretest having only twelve (12) readers to have reached this level to forty-one (41) during the posttest. The findings revealed that there is a significant difference between the word reading pretest score and word reading posttest score after the Library Hour intervention. These results were strengthened through the study conducted by Nijoku et al. (2020) in which one way of improving the reading habit of students is to have a functional library. They proposed that students must engage in continuous reading activities. 
Table 3. Significant difference on the word reading level of the Grade V pupils before and after the Library Hour intervention

\begin{tabular}{|c|c|c|c|c|c|c|}
\hline \multirow{2}{*}{$\begin{array}{l}\text { Reading } \\
\text { Level }\end{array}$} & \multicolumn{2}{|l|}{ Pre-Test } & \multicolumn{2}{|l|}{ Post-Test } & \multirow[t]{2}{*}{ t-Test } & \multirow{2}{*}{$\begin{array}{l}\text { t-crit } \\
@ 0.05\end{array}$} \\
\hline & Frequency & Percentage & Frequency & Percentage & & \\
\hline Frustration & 34 & 47.22 & 3 & 4.17 & & \\
\hline Instructional & 26 & 36.11 & 28 & 38.89 & $14.36^{* *}$ & 1.99 \\
\hline Independent & 12 & 16.67 & 41 & 56.94 & & \\
\hline
\end{tabular}

\section{Word reading level of the Grade V pupils before and after the Library Hour intervention when grouped according to Sex}

Table 4 presents the word reading level of the Grade V pupils before and after the Library Hour intervention when grouped according to gender. The t-test value of 0.874 is lower than the critical value of 1.99. This means that when the t- test value is lesser than the critical value, the null hypothesis is accepted and the alternative hypothesis is rejected. This further means that both male and female grade five pupils does not differ with each other in their reading levels before and after the library hour intervention program. This indicates that the number of male and female pupils under the frustration level decreases from twenty-two (22) during the pretest to three (3) during the posttest for the males and from twelve (12) during the pretest to zero (0) during the posttest for the females. On the contrary, there is an increase in the number of pupils under the instructional level from pretest to posttest from sixteen (16) to seventeen (17) and from nine (9) to eleven (11) for males and females, respectively. Moreover, the number of pupils under the independent level also increases for both gender. During the pretest, there were only five (5) male pupils under independent level and the number increased to twenty-five (25) during the posttest. Also, there were only eight (8) female pupils who have reached independent level during the pretest but the number increased to eighteen (18) during the posttest. Findings revealed that there was no significant difference between the male and female grade five pupils in their word reading level after the library hour intervention. This means that library hour as a reading intervention program is effective for both gender.

Table 4. Word Reading Level of the Grade V Pupils before and after the Library Hour Intervention When Grouped According to Sex

\begin{tabular}{|c|c|c|c|c|c|c|}
\hline \multirow{2}{*}{$\begin{array}{l}\text { Reading } \\
\text { Level }\end{array}$} & \multicolumn{2}{|l|}{ MALE } & \multicolumn{2}{|c|}{ FEMALE } & \multirow[t]{2}{*}{ t-Test } & \multirow{2}{*}{$\begin{array}{l}\text { t-crit } \\
\text { @ } 0.05\end{array}$} \\
\hline & Pre-test & Post-test & Pre-test & Post-test & & \\
\hline Frustration & 22 & 3 & 12 & 0 & & \\
\hline Instructional & 16 & 17 & 9 & 11 & $0.874^{\mathrm{ns}}$ & 1.99 \\
\hline Independent & 5 & 23 & 8 & 18 & & \\
\hline
\end{tabular}

\section{CONCLUSIONS AND RECOMMENDATIONS}

The following conclusions were drawn based from the statistical analyses of the data: (1) The pupils are instructional readers. This means that the teacher needs to instruct the pupils in reading during reading time for the grade five pupils to read correctly and accurately; (2) The pupils are at the highest reading level (Independent reading level). They have sufficient background knowledge for the lesson and can easily access text and with less errors. They can read without help; (3) The Library hour reading intervention program is effective in developing the reading skill of the Grade Five pupils as manifested 
in the result of the posttest; and (4) The proposed reading intervention program is effective regardless of the gender of the pupils. In the light of the findings, the researchers recommend the following: (1) Teachers may constantly give instructions prior to reading such that pupils will be able to read better and will gradually improve their reading performances. The teacher may determine the type of modeled direction instruction needed to attain the skill; (2) Provisions of reading material resources should be given to pupils to sustain their reading capabilities; (3) Schools must include library hour in the school classroom programs to improve the word reading levels of pupils; (4) Teachers must prepare varied reading materials inside the classroom in order for the pupils to equally adopt good reading strategies that will make them good readers; and (5) Further research on reading intervention programs emphasizing the development of comprehension skills.

\section{ACKNOWLEDGEMENT}

The authors would like to express their appreciation to the graduate school of the University for the assistance and constructive analysis of the results of the study.

\section{REFERENCES}

Asagwara, C. G. (2001). Study habits dimensions and effective application in schools. Calabar, Nigeria: Sea fruit Company.

Balan, S., Katenga, J. E., \& Simon, A. (2019). Reading Habits and Their Influence on Academic Achievement Among Students at Asia Pacific International University. International Scholars Conference, Volume 7 Issue 1. https://doi.org/10.35974/isc.v7i1.928

Daniel, O. C., Esoname, S. R., Chima, O. D., \& Udoaku, O. S. (2017). Effect of Reading Habits on the Academic Performance of Students. A Case Study of the Students of Afe Babalola University, Ado-Ekiti, Ekiti State. Teacher education Curriculum Studies. Vol. 2, No. 5, pp. 74-80. doi: https://doi.org/10.11648/j.tecs.20170205.13

Deavers, R. (2000). The effect of instruction on early no-word reading strategies. Journal of Research in Reading. 23, 267-286.

Department of Education-Bureau of Learning Delivery (2018). The Philippine Informal Reading Inventory Manual

$\begin{array}{llll}\text { Department } & \text { of } & \text { Memorandum } & \text { No. }\end{array}$ https://www.officialgazette.gov.ph/2011/10/02/memorandum-no-244-2-2011/

Douglas, M.P. (2000). Primary school library and its services, Paris: UNESCO; In Nwokocha, O.V. 2014. Comparative study of the reading habit of day and boarding secondary school students in the federal capital territory (FCT), Abuja, Nigeria. Researcher, 6 (6): 40-46. http://www.sciencepub.net/researcher.

Flippo, R. (2014). Assessing readers qualitative diagnosis and instruction. Second Edition. Routledge, New York. http://www.reading.Org/Libraries/books/assessing-readers-seconded-chapter3.pdf Copublished with Routledge/taylor \& Francis.

Issa, A. O., Aliyu, M. B., Akangbe, R.B. \& Adedeji, A. F. (2012). Reading interest and habits of the polytechnic students. International Journal of Learning \& Development. 2(1), 470-486.

Korantwi-Barimah, J. S., Ofori, A., Nsiah-Gyabaah, E., \& Sekyere, A. M. (2017). Relationship between motivation, academic self-concept and academic achievement amongst students at a Ghanaian Technical University. International Journal of human Resource Studies, 7910, 61-73.

Krashen, S. (2004). The power of reading. Westport, CONN: Libraries Unlimited and Portsmouth, NH: Heinemann. (OcoLC)676867950

Liu, Y., \& Hou, S. (2017). Potential reciprocal relationship between motivation and achievement: A longitudinal study. Social Psychological International. https://doi.org/10.1177/0143034317710574

Ogbodo, R.O. (2010). Effective study habits in educational sector: Counseling implications. Edo Journal of Counseling, 3(2), 1-11.

Omela, E. T., \& Martin, M. D. M. (2020). Teachers' motivational strategies employed in teaching passive pupils. $\begin{array}{lllll}\text { EDUCATUM Journal of Social } & \text { Sciences, } & 6(1), & 1-11 .\end{array}$ https://ejournal.upsi.edu.my/index.php/EJOSS/article/view/2805

Lehr, F., Osborn, J. \& Hiebert, E. H. (2004). A focus on vocabulary. Pacific regional Education Laboratory. http://www.prel.org/programs/rel/vocabularyforum.asp 
Nijoku, E. o., Okore, A. O., \& Osadebe, N. E. (2020). Enhancing Literacy Learning among Primary School Pupils in Nsukka Local Government Area of Enugu State: The Role of the Children's Centre Library, university of Nigeria, Nsukka. Library Philosophy and Practice (e-journal). 3984. https://digitalcommons.uni.edu/libphilprac/3984

Palani, K. K. (2012). Promising reading habits and creating literate social. International Reference Research Journal Vol. III Issue 2(1), 91.

Philippine Informal Reading Inventory (2009). Department of Education. R.A. 10533, The Enhanced Basic Education Act of 2013.

Rutledge, S. (1998). Informal Reading Inventory. Retrieved from http://lrs.ed.uiuc.edu/students/srutledg/iri.html.

Sharma, R., Rana, D. K., Ghai, S. (2019). Research Design. https://www.researchgate.net/publication/335651908

Torgesen, J. K. (2005). Recent discoveries on remedial interventions for children with dyslexia. In M. J. Snowling \& C. Hulmw (Eds.), The Science of Reading: A Handook 521-537. Oxford: Blackwell.

Tracy, J. \& Matsumoto, D. (2008). The Spontaneous expression of pride and shame: Evidence for biologically innate nonverbal displays. https://doi.org/10.1073/pnas.0802686105

Weaver, B. (2014). Formal vs informal assessments. Retrieved from http://lrs.ed/students/srutledg/iri,html 